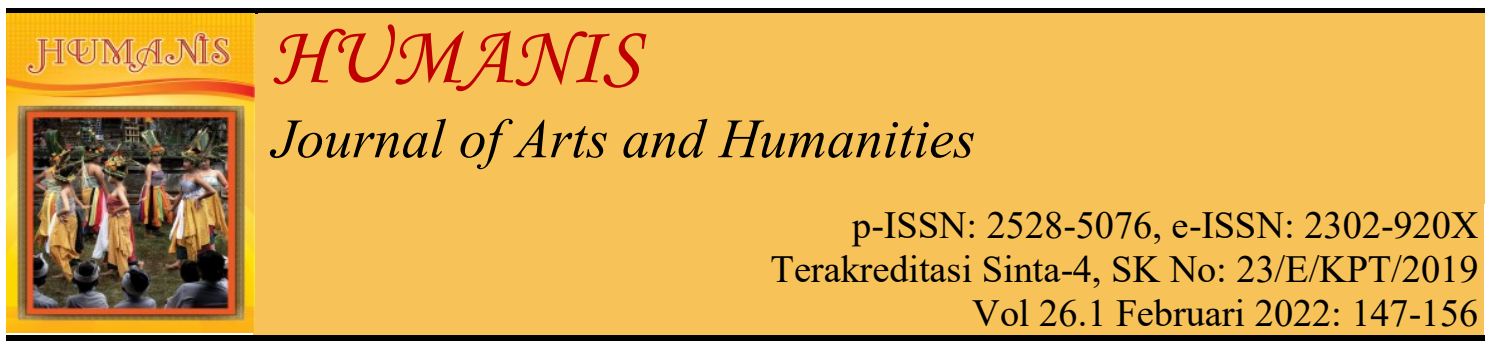

\title{
Eksistensi Desa Muslim Kampung Kusamba tahun 1990 - 2015
}

\author{
Yudha Aditama, A.A Bagus Wirawan, A.A Rai Wahyuni \\ Universitas Udayana, Denpasar, Bali, Indonesia \\ Email Korespodensi: yudhaaditatama@yahoo.com, baguswirawan@gmail.com , \\ raiwahyuni@gmail.com
}

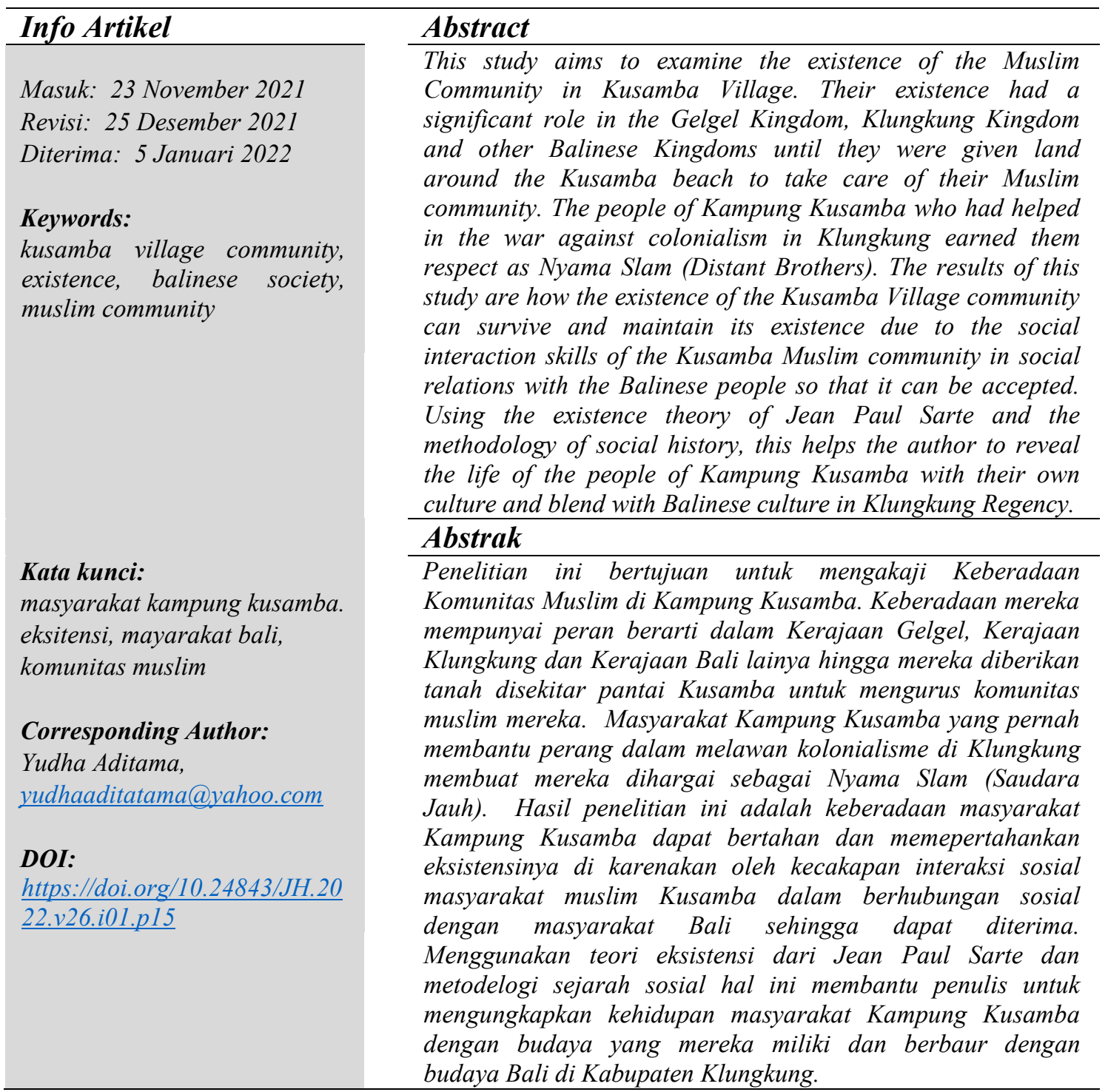

\section{PENDAHULUAN}

Provinsi Bali merupakan wilayah yang terbagi menjadi bagian wilayah hingga desa, perlu mendapat perhatian untuk diteliti.Keberadaan wilayah desa Kampung Kusamba yang warganya berperan pada kerajaan di Bali sangat menarik untuk diteliti. Melihat eksistensi 
desa Kampung Kusamba dapat diketahui dengan keunikan warganya yang beragama Islam di tengah keberadaan desa desa yang warganya mayoritas pemeluk agama Hindu di Bali.

Kedatangan Islam di Bali terjadi ketika zaman Kerajaan Gelgel.Kerajaan Gelgel merupakan bawahan dari kerajaan Majapahit pada masa pemerintahan Hayam Wuruk.Upaya yang dilakukan Kerajaan Gelgel dalam membendung pemberontakan tersebut dengan mendatangkan bala bantuan dari Jawa untuk memadamkan pasukan tersebut.

Kerajaan Gelgel yang berhasil direbut oleh I Gusti Agung Maruti telah rata dengan tanah tidak dapat dipulihkan kembali akibat peperangan.Setelah takluknya pemberontakan Patih Maruti berdiri Kerajaan Klungkung pada awal abad ke - 16 mengantikan Kerajaan Gelgel. Raja Klungkung mengapresiasi laskar Jawa yang beragama Islam dengan menempatkannya di pesisir pantai Desa Kusamba menjadi kantong pelindung Kerajaan Klungkung. Hal itulah yang menyebabkan Kerajaan Klungkung menjadi sasuhunan raja - raja di Bali pada abad ke - 19 .

Sejarah Desa di pantai Kusamba sama-sama memberikan arti penting bagi kehidupan masa kini. Dahulu sebelum Dewa Agung Istri Kanya selaku penguasa Kerajaan Klungkung,Desa Kusamba merupakan Ibu kota ke dua Kerajaan Klungkung ketika di pimpin Ida I Dewa Agung Putra Kusamba tahun 1790 1809. Atas dasar mendukung pemerintahannya, Ida Idewa Agung Putra Kusamba pun mendirikan istana di Desa ini dengan nama Kusanegara. Selain membangun istana, Kusamba juga dijadikan sebagai kota pelabuhan dan banteng Kerajaan.(Artanegara, 2019).

Kebijakan I Dewa Agung Putra Kusamba menjadikan Desa Kusamba sebagai kota pelabuhan karena melihat strategisnya geografis yang berada dekat pantai dan muara yang tenang dan luas serta bersatu dengan laut. Berkembangnya Desa Kusamba sebagai kota pelabuhan membuat Belanda ingin menguasai kota pelabuhan tersebut. Kedatangan Belanda ketika abad XVI yang dipimpin oleh Laksamana Cournelis Heemkereck berawal dari keinginan untuk mengadakan hubungan perdagangan dengan Pulau Bali.(Agung, 1989).

Masuknya suku Bugis dari Sulawesi dan suku Banjar ke Bali di Desa Kusamba dilatarbelakangi juga oleh Desa Kusamaba sebagai Kota Pelabuhan.Awalnya orang Bugis dan suku Banjar menjelajahi lautan sebagai bentuk pelarian mereka terhadap perlawanan Belanda.Mulanya Suku Bugis mendarat di Pulau Serangan yang menjadi cikal bakal kampung Bugis. Setelah itu karena orang Bugis banyak yang berniaga maka sampai ke kota pelabuhan Kampung Kusamba. Namun suku Banjar baru masuk ke Bali karena mereka terdampar di kota pelabuhan yaitu Pelabuhan Kusamba. Lambat laun masyarakat migran yang merupakan saudagar dari Bugis dan suku Banjar mulai banyak populasinya di Kampung Kusamba menambah populasi umat muslim yang ada di Bali. Nama Kusamba konon berawal ketika seorang muslim suku Banjar merapat ke pantai desa itu. Ketika orang Banjar melihat seseorang yang merupakan asal Bugis sedang sholat lantas didekatinya dan bertanya siapa kamu dan menjawab "kusama" namun yang terdengar oleh suku Banjar itu adalah "kusamba". Berdasarkan percakapan suku Bugis dan suku Banjar menjadi asal mula Desa Kusamba.

Masyarakat Desa Kampung Kusamba kini terkenal dengan nelayan dan petani garamnya.Bali juga terkenal sebagai provinsi yang memproduksi garam dalam jumlah yang besar. Dimana Kampung Kusamba juga termasuk daerah yang memproduksi garam bagi 
Bali Salah satu daerah yang sampai saat ini masih memproduksi garam dalam jumlah yang besar yaitu Desa Kampung Kusamba, Kecamatan Dawan, Kabupaten Klungkung, Bali. Daerah dekat dengan pesisir pantai dan lautan membuat mayoritas masyarakat Kampung Kusamba bermatapencarian sebagai petani garam dan nelayan

Ada juga yang bergelut di sektor usaha mikro seperti berdagang. Pekerajaan lain yang digeluti karyawan swasta, pegawai negri, penjual jasa transport peneyebrangan. Menurut Muhamad Darso perkerjaan sebagai nelayan dirasa cukup saja untuk memenuhi kebutuhan rumah tangga dan biaya anaknya sekolah.Ada juga seperti Ahmad Budarman warga kampung yang juga nelayan sekaligus memproduksi garam sebagai mata pencariannya.

Keunikan yang dimiliki desa Kampung Kusamba yaitu terdapat pada masyarakatnya, dimana mayoritas masyarakatnya beragama islam namun rata-rata memakai penamaan orang Bali, salah satu contoh adalah bapak Wayan Muhammad Saddar yang memeluk agama Islam namun namanya mengandung nama orang Bali. Nama Bali yang digunakan oleh masyarakat Desa Kampung Kusamba adalah ciri khas muslim didesa tersebut. Menurut Bapak Hambali ada suatu tradisi yang terdapat di desa Kampung Kusamba yaitu ada acara khusus yang dinamakan safara.

Perbedaan agama antara desa Kampung Kusamba dengan desa lainnya yang ada di Kabupaten Klungkung tidak menjadi persoalan untuk membuka pandangan toleransi sesama masyarakat desa. Dikarenakan catatan sejarah mengenai peranan umat islam, perkawinan, kesamaaan profesi sebagian besar nelayan, dan alasan sosial dengan menciptakan kehidupan sosial yang rukun antar masyarakat membuat toleransi kuat disana. (Afandi, 2012).
Desa Kampung Kusamba hingga kini terdiri multietnis seperti Bugis, Banjar, Sasak, dan Bali. Hak Otonomi mengurus daerah adminitrasif sendiri menjadikan kampung kusamba terkenal pluralitasnya. Sebenarnya dalam peraturan pemerintah, desa setidaknya memilki 400 KK (Kepala Keluarga). Menurut data desa Kampung Kusamba tahun 2016 hanya terdapat $190 \mathrm{KK}$ dengan jumlah penduduk 333 jiwa laki laki dan 357 jiwa perempuan. Dikarenakan daerah kampung Kusamba merupakan daerah warisan sejak zaman kerajaan Klungkung maka keberadaan desa tetap dipertahankan.

Kampung kusamba memang terkenal dengan komunitas muslimnya. Hal inilah yang membuat eksistensi kampung tersebut terkenal dengan keberagaman etnis masyarakat di Provinsi Bali. Diterimanya masyarakat Kampung Kusamba oleh masyarakat desa lain tidak lepas dari bentuk adaptif mereka. Cara yang digunakan adalah mengagungkan budaya lokal dan komunikasi dialektik yang baik. Hubungan komunikasi dialektik yang dibangun oleh masyarakat Kampung Kusamba maupun sebaliknya dengan kearifan lokal Bali.

Menjadi komunitas muslim pertama di Bali yaitu Desa Kampung Kusamba, mereka cukup disegani oleh masyarakat sekitar yang mayoritas agama hindu. Kehidupan masyarakat Kampung Kusamba juga dijalani dengan rukun, damai, penuh toleransi, bahakan terjadi akulturasi, dan kawin silang antara Islam dan Hindu. Sehingga Bali menjadi wilayah yang kondusif bagi toleransi beragama.

Persoalan bagaimana cara Desa masyarakat Kampung Kusamba dapat mempertahankan terhadap identitasnya, mempertahankan bukti sejarah masuknya Islam dan akulturasi Budaya, hak otonomi mengurusnya daerahnya sendiri 
dan berdiri dalam perekonomian mandiri. Kesemua itu sangat menarik untuk diteliti lebih lanjut tentang yang ada pada eksistensi Desa Kampung Kusamba, Kabupaten Klungkung, Provinsi Bali.

Tujuan dari penelitian ini adalah untuk mengetahui (1)Bagaimana proses masuknya agama Islam di Kabupaten Klungkung Provinsi Bali ? (2)Faktor faktor apa saja yang mempengaruhi eksistensi Desa Muslim Kampung Kusamba di Kabupaten Klungkung Provinsi Bali ?dan (3) Apa implikasi dari eksistensi Desa Muslim Kampung Kusamba di Kabupaten Klungkung Provinsi?

\section{METODE DAN TEORI}

Penulisan menggunakan metode sejarah sosial. Metodologi adalah ilmu yang membicarakan jalan. (Kuntowijoyo, 2003). Dengan kata lain diperlukannya untuk mengkaji atau approach untuk meneliti dengan mendekati objek studinya. (Kartodirdjo, 1992: ix). Metodologi juga merupakan kerangka pemikiran (frame works) tentang konsep, kategori, model, hipotesis dan prosedur umum untuk menyusun teori. ( Pranoto, 2010: 11).

Kaitannya pendekatan sejarah sosial yang digunakan penulis dalam penelitian ini untuk merekontruksi bagaimana bertahannya eksistensi Desa Kampung Kusamba yang didalamnya dipengaruhi oleh faktor serta peran masyarakat Kampung Kusamba. Berdasarkan upaya upaya yang dilakukan masyarakat Desa Kusamba agar dapat diterima dalam ruang ruang sosial sehingga dapat diterima dan bertahan eksistensi Desa Kampung Kusamba

Sejarah sosial yang dikatakan oleh Kuntowijoyo mempunyai hubungan yang erat dengan sejarah ekonomi dan menjadikannya sebagai sejarah sosialekonomi. Perkembangan sejarah terlihat dalam dinamika masyarakat karena adanya kekuatan-kekuatan sejarah yang berupa kekuatan alam. Seperti ada dan tidaknya sumber-sumber ekonomis, pertumbuhan penduduk, kepentingan-kepentingan kelas, grup dan individu, penemuan teknologi baru, ideologi, kepercayaan, pengaruh dari luar dan sebagainya.(Gottscalk, 1990). Model yang akan digunakan oleh penulis adalah model tingkat perkembangan. Penerapan metodologi sejarah sosial dalam penelitian ini, lebih condong terhadap masyarakat yang berusaha didalamnya mempertahankan dirinya, kemudian mengatur hubungan antar sesamanya (status dan wibawa), dan mencoba mencari solusi di lingkungannya baik alamiah ataupun sosial (Soekanto, 1982).

Teori merupakan salah satu terpenting dalam pengembangan ilmu pengetahuan dan penelitian, tanpa teori, tidak ada ilmu pengetahuan. Secara pengertiannya teori adalah suatu perangkat kaidah yang memandu sejarawan dalam penelitian dan menyusun bahan-bahan (data, bukti) yang diperolehnya dari analisis sumber dan juga dalam mengevaluasi hasil penemuannya.

Menggunakan teori eksistensi dari Jean Paul Sartre dirasa penulis sangat membantu dalam menjawab bertahannya eksisitensi Desa Kampung Kusamba. Penjabaran teori ini dapat membantu mengetahui dalam aktivitas masyarakat dengan hubungan Desa Kampung Kusamba. Pengertian eksistensi menurut Jean Paul satre adalah suatu proses yang dinamis, suatu, menjadi atau mengada. Hal ini sesuai dengan asal kata eksistensi yakni exsistere yang artinya keluar dari, melampaui atau mengatasi.

Hadiwijono, 1998)

Pengertian eksistensi disini tidak bersifat kaku dan terhenti, melainkan lentur atau kenyal dan mengalami perkembangan atau sebaliknya kemunduran, hal itu tergantung pada kemampuan dalam mengaktualisasikan 
potensi potensinya. Eksitensi dikenal juga dengan keberadaan bahwa keberadaan yang dimaksud adanya pengaruh atas ada atau tidak adanya seseorang. Maka itu berkaitan dengan eksisitensi Desa Kampung Kusamba pada masyarakatnya.

Jean Paul Satre mendefinisikan bahawa eksistensi kita mendahului esensi kita. Selanjutnya kita mempunyai pilihan bagaimana kita menjalani hidup dan membentuk serta menentukan siapa diri kita. Esensi manusia adalah kebebasan dimana hal yang ada pda diri manusia membedakan kita dari apapun yang ada di alam semsesta ini. Kita sebagai manusia masing masing memilki modal beraneka ragam namun memilki kesamaan tugas dalam membentuk diri kita sendiri.

Penyesuain dengan teori tersebut "kita" memilki arti masyarakat Kampung Kusamba dan "alam" yang dimaksud adalah Desa Kampung Kusamba. Keberadaan Desa Kampung Kusamaba yang dapat bertahan dengan situasi ekonomi, politik dan budaya merupakan proses pendorong aktivitas masyarakat untuk bertanggung jawab atas bertahannya eksistensi desa mereka. Hal ini lah yang membuat cocok dimana teori tersebut bagaimana masyarakat Desa kampung Kusamba membentuk dirinya agar dapat terus bertahan pada eksistensi Desa Kampung Kusamba.

\section{HASIL DAN PEMBAHASAN}

\section{Proses Masuknya Agama Islam di Kabupaten Klungkung}

Ada banyak proses masuknya agama Islam ke Bali. Islam masuk dan diterima dikarenakan peran yang begitu besar bagi Kerajaan Bali. Peran-peran tersebut sangatlah penting bagi kehidupan masyarakat Bali pada dewasa kini sebagaimana mengusir penjajahan atas kolonialisme Belanda. Atas dasar agama Islam bisa masuk dan berkembang di Bali walaupun masyarakat Bali sudah memeluk agama Hindu sebagai kepercayaanya.

Sejarah awal masuknya Islam di Bali paling tidak, ada dua teori yang umum digunakan oleh para penulis sejarah Islam di Bali. Teori pertama, Islam datang ke Gelgel pada abad ke-14 masa pemerintahan Dalem Ketut Ngelesir, raja Gegel pertama. Ada 40 orang pengiring raja Ketut Ngelesir yang mengiringi perjalanannya sehabis kunjungan ke Majapahit. Pengiring kerajaan yang merupakan beragama Islam dari Jawa kemudian tinggal di Gelgel dan mereka hidup menjadi abdi dalem pemerintah , kemudian diberikan tempat di Gelgel, di sana dibangunlah masjid, kuburan, dan perkampungan.

Kemudian periode masuknya Agama Islam ke Bali hingga ke Kabupaten Klungkung telepas runtuhnya masa kejayaan Kerajaaan Majapahit dengan bergantinya dominasi Kerajaan Islam di Nusantara.. Islam datang pada saat keruntuhan Majapahit pada abad ke-16, saat itu rajanya adalah Ida Dalem Waturenggong. Ada tiga orang utusan dari kerajaan Demak datang ke Gelgel, mereka adalah Ki Moder, Ki Jalil dan Dewi Fatimah. Gelombang berikutnya berasal dari utusan Demak yang gagal mengislamkan Kerajaan Bali. Nama "Demak" memang sering penulis temukan di banyak buku rujukan tentang peristiwa pasca Kerajaan Majapahit, karena kemudian muncul menjadi pusat penyebaran agama Islam, sehingga diberi julukan kota Mekah di kawasan Nusantara.(Khusyari, 2015).

Gelombang Islam masuk ke Bali berikutnya terjadi pada masa Raja Klungkung, menurut cerita setempat, sekitar tahun 1690 Anak Agung Ketut Karangasem menyerang Pulau Lombok. Dalam penyerangan tersebut, Raja Karangasem berhasil menaklukkan Kerajaan Pejanggik dan menguasai 
sebagian wilayah Kerajaan Mataram atas jasa Pangeran Dadu Ratu Mas Pakel, putra Raja Mataram. Sebagai tanda jasa Pangeran Dadu Ratu Mas Pakel beserta pengikutnya yang beragama Islam diberi tempat terhormat di Karangasem. Ketika meninggal jasad Sang Pangeran dimakamkan di di Istana Taman Ujung. (Wahid, 2011).

Komunitas inilahyang menjadi cikalbakal kampung-kampung Islam di wilayah Karangasem. Data sejarah yang merujuk pada cerita setempat diperkuat dengan pernyataan Ustadz Drs. Taufiq Ashadi (Ketua MUI Bali), bahwa kehadiran Islam di Karang Asemadalah "generasi kedua, waktu itu Kerajaan Karang Asem menguasai Lombok, lantas sebagian orang-orang Lombok juga dibawa kemari untuk menjaga Puri Karang Asem, kemudian umat Islam mengelilingi puri sebagai abdi dalem. Sebab itu di Karang Asem sekarang ada 56 Masjid, musholla dikasih tanahnya pada zaman Kerajaan". Sejak menguasai Lombok, Raja Karangasem sejak saat itu membina hubungan baik dengan umat Muslim di Lombok. (Suwinda, 2012). Sebagian dari merekakemudian bermigrasi dari Lombok ke Karangasem.

\section{Faktor Faktor yang mempengaruhi Eksistensi Desa Kampung Kusamba}

Pembahasan mengenai faktor yang menyebapkan eksistensi Desa Kampung Kusamaba menarik karena masih eksis hingga tahun 2015 sesuai pembatasan masalah penelitian. faktor faktor yang menyebapkan yaitu faktor peran historis yang diciptakan masyarakat Kampung Kusamba dan Faktor Kecakapan interaksi sosial yang terjalin dengan masyarakat sekitar, faktor ekonomi dan faktor budaya

\section{a. Faktor Peran Historis}

Masyarakat Kampung Kusamba mempunyai peran historis yang menyebabkan terjalinnya eksistensi pada Desa Kusamba antara krama Hindu dengan Islam berawal terjadinya pemberontakan Patih Maruti, di mana Raja Gelgel banyak mendatangkan bala pasukan dari Jawa untuk membantu memadamkan pemberontakan tersebut. Setelah takluknya Patih Marutimaka raja menempatkan pasukan dari Jawa yang beragama Islam di pesisir pantai Desa Kusamba. Mereka bertugas sebagai benteng pertahanan, untuk menahan bila ada ancaman musuh yang datangnya dari sebelah timur. Dengan demikian, kerajaan Gelgel sebagai sasuhunan rajaraja di Bali tetap ajeg.

Atas jasa pasukan Islam tersebut dalam peperangan melawan Belanda lalu mereka diberikan tempat (wilayah tempat tinggal) tersendiri untuk mengurus komunitasnya tersendiri (daerah otonom) di Desa Kusamba. Dengan demikian, sampai saat ini wilayah tempat tinggalnya menjadi sebuah Desa otonom yang bernama Desa Kampung Kusamba. Dalam catatan sejarah lainnya disebutkan bahwa Desa Kampung Kusamba, Klungkung memiliki ikatan yang sangat besar atas perkembangan Islam di Tanah Dewata.

b.Faktor Kecakapan Interaksi Sosial

Cara untuk tetap pada jalur eksistensi masyarakat Kampung Kusamba yaitu dengan kecakapan interaksi sosial. Interaksi yang dibangun antara umat Hindu dan umat Muslim menciptakan gesekan yang dinamis pada pergerakan kehidupan masyrakat Kampung Kusmaba. (Segara, 2018). Sejarah perjumpaan antara Hindu dan Islam seperti di atas membawa akibat denganlahirnya akulturasi kebudayaan, meskipun hasil akulturasi ini dijiwai sepenuhnya oleh ajaranagama Hindu, seperti Tat Twam Asi, Tri Hita Karana, atau Wasudewa Kutum Bakam. Namundalam praktik sosialnya dilakukan melalui kearifan lokal Bali, seperti menyama braya, metulungan, dan ngejot.(Samarajaya, 2021). 
c. Faktor Ekonomi

Masyarakat Kampung Kusamba dapat berkembang dengan ekstensinya dikarenakan faktor ekonomi dalam bidang produksi garam yang telah dikenal luas. Produksi garam yang telah dijalankan turun temurun sebagai petani garam laut (garam organik) membuat desa Kampung Kusamba dengan geografis daerah dekat pantai sangat cocok bagi masyarakatnya sebagai mata pencarian.

Kegiatan bertani garam ini dilakukan dengan cara manual dan peralatan tradisional. Meskipun jumlah petani garam semakin hari semakin menurun jumlahnya, tetapi para petani yang tersisa masih gigih mempertahankan usahanya untuk memenuhi kebutuhan perekonomian keluarganya.

Pantai dari dulu sampai sekarang merupakan jantung ekonomi, jantung mata pencahariaan masyarakat Desa Kusamba. Menginjakkan kaki di Pantai Kusamba, dari kejauhan kita sudah bisa melihat nuansa gubuk bambu yang merupakan tempat para petani garam mengolah dan menyimpan garam hasil dari kerja kerasnya. Biasanya di tempat pengolahan garam akan kita lihat lahan luas dengan pasirnya yang bersih dan lembut sebagai ladang pembuatan garam, bilahbilah pohon kelapa yang dibuat palung untuk proses pengkristalan garam dan gubuk sebagai pengolahan air garam dan penyimpanan garam jadi.

\section{d. Faktor Budaya}

Faktor budaya yang menunjang esistensi Kampung Kusamba yaitu aspek pariwisata. Kuatnya unsur budaya diantara masyarakat Kampung Kusamba dengan berbagai etnis Jawa, Bugis dan Banjar dan etnis lain melahirkan ciri yang menarik sebagai ekstensi Desa Kampung Kusamaba. Pariwisata yang berkembang dalam kultur masyrakat Muslim di Bali seperti Kusamba adalah wisata religi.
Wisata religi seperti makam tua, tempat peribadatan yang terakulturasi budaya Bali dan Jawa (etnis lain) hal ini yang menyebapkan ketertarikan berbagai dimensi masyarakat untuk berwisata yaitu mencari tahu keberadaanya. (Malik, 2016).

Seiring dengan perjalanan waktu. Dewasa ini, pulau ini sedang menghadapi tantangan berat, bersamaan berubahnya panorama ekonomi-politik, sosial-agama (budaya). Di sisi lain Pulau ini membutuhkan dunia luar (wisatawan, modal, dan tenaga kerja murah). Hal itu ditandai dengan mengalirnya arus imigrasi dari luar Bali. Namun di sisi lain dengan kehadiran pengaruh dari dunia luar tersebut, rakyatnya merasa terancam oleh kekuatan luar (investor besar, dekandensi barat, dan Islam).

Nordholt (1995), mencirikan Bali sebagai benteng terbuka yang menerima pengaruh luar seraya berjuang melindungi diri darinya. Melihat Bali dalam konteks keindonesiaan dewasa ini tentu tidak lepas dari perkembangan industri pariwisata dengan faktor sosiobudaya yang dimiliki masyarakat Bali. (Madiun, 2010).

\section{Implikasi Terhadap Eksistensi Desa Muslim Kampung Kusamba}

Implikasi pada Eksistensi Desa Kampung Kusamba yang terjadi berpengaruh terhadap aspek internal dalam wilayah masyarakat dan aspek eksternal diluar wilayah masyarakat tersebut. Hal itu terjadi karena sebuah proses dan faktor sebagai jalan terhadap implikasi Desa Kampung Kusamba.

Maka dari itu langkah Desa Kampung Kusamba seperti sekarang menjadi sebuah konsekuensi tanpa disadari ataupun disadari. Pada dasarnya dampak eksistensi Desa Kampung Kusamba dalam kehidupan sosial, (Haman, 2021) masyarakat dituntut untuk menyesuaikan diri dengan tradisi 
masyarakat setempat. (Suarsana, 2011) Karena hal itu sejalan dengan bagaimana mendapat keberhasilan melalui interaksi sosial dengan masyarakat sekitar wilayah Kampung Kusamba. Adapun dampak yang terjadi pada eksistensi pada Desa muslim Kampung Kusamba sebagai berikut.

\section{a. Akulturasi budaya Bali}

Akulturasi yang ada pada Desa Kampung Kusamba terdapat percampuran budaya lokal (Bali) dengan berbagai etnis yang ada pada Kampung Kusamba. Etnis seperti Jawa, Bugis, Banjar, menjadi dominasi akulturasi budaya yang terdapat dikampung Kusamba. (Suwindia, 2012) Akluturasi tersebut dilihat pada tradisi yang dimilki masyarakat Kampung Kusamba, seni yang berkembang dan bentuk bangunannya. Berikut akulturasi yang terdapat di Kampung Kusamba seperti Tradisi Saparan, Tradisi Safara, tradisi Muharam, Tradisi Megibung.(Segara, 2010)

\section{b. Toleransi Yang Berkembang}

Berdasarkan usaha dan perjuangan para tokoh masyarakat di Desa Kusamba baik yang beragama Hindu maupun yang beragama Islam maka penanaman sikap toleransi sudah tumbuh subur. Hal itu dapat dibuktikan dalam kehidupan sosial, warga dapat hidup berdampingan dan saling harga menghargai dalam berbagai aktivitas. (Diah, 2018)

Dengan demikian, mereka dapat menjalankan berbagai usaha untuk kepentingan mencari nafkah hidup seharihari atau menjalankan usaha untuk meningkatkan perekonomian. Dengan adanya rasa aman dan nyaman dalam kehidupan sosial (tanpa adanya sekatsekat sosial) maka warga setempat akan dapat menjalankan tujuan hidupnya dengan baik. ( Yudhabakti, 2021)

Hal inilah yang telah terwujud, yaitu sikap toleransi yang sudah menjadi kepentingan hidup. Tumbuhnya hal ini harus diusahakan dengan dibina secara kontinyu dan diawasi secara intensif layaknya memelihara tanam tanaman untuk mendapat hasil yang baik dan bermanfaat bagi kehidupan kita di dunia ini. Jika hal toleransi telah terbukti mampu mandamaikan pikiran dan sikap warga di Desa Kusamba maka mereka tidak ragu lagi untuk melakukan antara warga yang berbeda agama.

\section{c. Mempunyai warisan sejarah Islam}

Warisan Sejarah agama Islam yang ada di Kampung Kusamba meninggalan bukti sejarah yang berguna sebagai pemahaman jadi diri kultur masyarakat. Selain warisan sejarah islam sebagai asset pariwisata bagi Desa Kampung Kusamba untuk orang yang menegetahui bukti bukti sejarah tentang islam di Bali. Adapun berupa akam-makam kuno yang memiliki ciri khas berupa nisan yang terbuat daribatu yang diukir dengan ornamen-ornamen unik. Biasanya ornamen berbentukakar-akar dan bunga.(Sutama, 2015).

Makam dengan nisan berukir ini jumlahnya cukup banyak. Selain makam dengan nisan berornamen, terdapat satu makam yang dikeramatkan. Warga Kusamba, baik Hindu maupun muslim menyebutnya keramat. Makam keramat tersebut awalnya berbentuk seperti makam kuno lainyadengan bernisan batu. Namun, pada tahun 1995, makam ini dipugar oleh keluarga Abdul Gani, dan ditempatkan di dalam bangunan yang beratap seperti rumah. (Yuantoro, 2019)

Di luar makam keramat juga dibangun tembok yang memisahkannya dengan makamlain. Selain itu, di depan makam keramat juga didirikan monumen berbentukpatung tokoh bersorban dan berjubah putih yang mengendarai kuda putih. Tidakjauh dari patung dibangun pendopo terbuka sebagai tempat bagi para peziarah yangingin beristirahat 
Di kalangan warga Kampung Kusamba, ada perbedaan pendapat mengenaisejarah makam keramat. Beberapa warga meyakini bahwa makam ini adalahmakam seorang Habib. Habib Ali bin Abubakar al Hamid. Menurut tokohmasyarakat Kampung Islam Kusamba, Mugeni, semasa hidupnya, Habib Alidikenal sangat dekat dengan keluarga Kerajaan Klungkung. Bahkan, ia ditunjuk menduduki jabatan sebagai penterjemah atau ahli bahasa yang bertugas mengajarkan bahasa Melayu kepada Raja Dewa Agung Jambe.

Di Desa Kampung Kusamba memiliki peninggalan sejarah berupa AlQuran tua pada tahun 1700-an yang sampai saat ini masih terjaga dengan baik di Kantor Desa, Al- Quran ini adalah hadiah pernikahan orang Bugis. Dulu di Desa kampung Kusamba masing-masing suku memiliki masjid tersendiri, orang Bugis, Orang Banjar, dan Orang Pasuruan sama-sama memiliki masjid, tetapi karena raja bingung ketika ingin turun dan melihat ada banyak masjid, lalu masjid mana yang lebih dulu di singgahi raja agar tidak menumbulkan konflik, maka dijadikanlah satu masjid yang berada di dekat kantor Desa Kampung Kusamba.

\section{SIMPULAN}

Eksistensi Desa Kampung Kusamba dapat diketahui dengan keunikan warganya yang beragama Islam di tengah keberadaan desa-desa yang warganya mayoritas pemeluk agama Hindu di Bali. Desa Kampung Kusamba hingga kini terdiri multietnis seperti Bugis, Banjar, Sasak, dan Bali. Hak Otonomi mengurus daerah adminitrasif sendiri menjadikan Kampung Kusamba terkenal pluralitasnya. Cara yang digunakan adalah mengagungkan budaya lokal dan komunikasi dialtektik yang baik. Hubungan komunikasi dialektik yang dibangun oleh masyarakat Kampung
Kusmaba maupun sebaliknya dengan kearifan lokal bali.

Islam masuk ke Bali dimulai dari Kabupaten Klungkung yang diperkirakan pada abad ke-13 M dan 14 M melaluiKerajaan Gelgel. Selanjutnya eksistensi Kampung Kusamba memliki warisan sejarah agama Islam yang ada di Kampung Kusamba. Meninggalan bukti sejarah berguna sebagai pemahaman jati diri kultur masyarakat. Selain warisan sejarah Islam sebagai asset pariwisata bagi Desa Kampung Kusamaba untuk orang yang menegetahui bukti bukti sejarah tentang islam di Bali seperti makam keramat dan $\mathrm{Al}$ Quran yang menjadi cirri masyrakat Muslim.

Berbaurnya budaya Bali dengan Masyarakat agama Islam yang telah terbentuk dalam keseharian masyarakat Desa Kampung Kusamba Nilai-nilai kemanusian yang bersifat universal dan sekaligus kearifan lokal Bali membuat pemahaman terhadap keberagaman antara Muslim dan Hindu di Bali.

Rekomendasi untuk penelitian selanjutnya agar melanjutkan temporal ketika tahun mendatang dalam subjek keberadaan masyarakat Muslim di Bali.

\section{DAFTAR PUSTAKA}

Affandi, Nurkholik. (2012). Harmoni Dalam Keragaman (Sebuah Analisi tentang Konstruksi Perdamaian Antar Umat Beragama). Jurnal Komunikasi dan Sosial Keagamaan, XV(1).

Diah, Halimatusa. (2018). Peranan Modal Kultural dan Struktural dalam Menciptakan Kerukunan Antar umat Beragama di Bali. Jurnal Harmoni, (17)1.

Gede Agung, A.A. (1989). Perjuangan Rakyat dan Raja-Raja Menentang Kolonialisme Belanda 1808 - 1908. 
Yogyakarta: Gajah Mada University Press.

Gede Alit Semarajaya, Cokorda., \& Kohdrata, Naniek. (2021). Memotret Bentuk-Bentuk Toleransi di Desa Kampung Kusamba, Karangasem, Jurnal Segara Widya $l, 13(1)$.

Gottchalk, Louis. (1969). Mengerti Sejarah Diterjemahkan Oleh Nugroho Notosantoso. Jakarta: Universitas Indonesia UI Press.

Hadiwijono, Harun. (1980). Sari Sejarah Filsafat Barat 2. Yogyakarta: Kanisius.

Haman, R., Darmana, I., \& ., A. (2021). Gerakan Sosial (Wuat Wa'i) pada Masyarakat Desa Gurung Liwut. Humanis, 25(1), 93-102. doi:10.24843/JH.2021.v25.i01.p12

Kartodirdjo, Sartono. (1992). Pendekatan Ilmu Sosial Dalam Metodologi Sejarah. Jakarta: PT Gramedia Pustaka Utama.

Kuntowijoyo. (2003). Pengantar Ilmu Sejarah.Yogyakarta: Tiara Wacana.

Khusyairi, Johnny A. (2015). Berlayar Menuju Pulau Dewata Migrasi Orang - Orang Bugis - Makassar ke Bali Utara, Jurnal Jurusan Ilmu Sejarah Universitas Airlangga. (3)1.

Malik, Farmawati. (2016). Peranan Kebudayaan dalam Pencitraan Pariwisata Bali. Jurnal Kepariwisataan Indonesia: Jurnal Penelitian dan Pengembangan Kepariwisataan Indonesia, 11(1).

Madiun. N, (2010). Nusa dua model Pengembangan kawasan wisata
Modern, Denpasar; Udayana University Press

Segara, I Nyoman. (2020). Komunikasi Dialektik dalam Relasi Hindu dan Islam di Bali. Jurnal Program Studi Magister Ilmu Komunikasi Hindu Insititut Hindu Dharma Negeri. 2(3).

Segara, I Nyoman Yoga. (2018). Kampung Sindu: Jejak Islam dan Situs Kerukunan di Keramas, Gianyar, Bali. Jurnal Lektur Keagamaan, 16(2).

Suarsana, I. Nyoman (2011). Pustaka; Jurnal Ilmu Budaya, Udayana University Press. 3(1)

Sutama, Putu Adi. 2015. Komunitas Muslim di Desa Kampung Gelgel, Klungkung Bali, ( Latar Belakang Sejarah, Peninggalan dan Potensinya Sebagai Sumber Belajar Sejarah di SMA ). Singaraja : Jurnal Ilmu Sosial Universitas Pendidikan Ganesha, 4(2).

Suwindia, I Gede. (2012). Relasi Islam dan Hindu Perspektif Masyarakat Bali. Jurnal Al-UlumVolume, 12(1). 